\title{
Professional psychological selection of military personnel: structure and main characteristics
}

\author{
T.P. Skripkina ${ }^{1 *}$, D.V. Smirnov ${ }^{2}$, and V.M. Bolshakova ${ }^{3}$ \\ ${ }^{1}$ Russian State University for the Humanities, Vygotsky Institute of Psychology, Moscow, Russia \\ ${ }^{2}$ St. Petersburg Military Order of Zhukov Institute of the National Guard of the Russian Federation, \\ St. Petersburg, Russia \\ ${ }^{3}$ Russian Academy of National Economy and Public Administration under the President of the \\ Russian, Nizhny Novgorod, Russia
}

\begin{abstract}
The article examines the essential characteristics of professional psychological selection of military personnel through the analysis of professional selection and its structure. The problem of effective implementation of professional psychological selection is considered by the authors as a problem of mutual correspondence of the individual and the profession. It is noted that it is solvable only if a certain set of requirements is met: both the individual's requests for a certain type of professional activity, and the requirements of the activity itself for the subjective characteristics of the «person of labor». Professional selection of military personnel structurally includes: social selection; medical selection; professional psychological selection; educational and qualification selection; assessment of the level of functional development and general physical fitness. The scientific results of the study include the fact that the general characteristics of the candidate and the military specialist performing professional psychological selection, the conditions and means of its implementation are disclosed.
\end{abstract}

\section{A problem statement}

The definition of the main ways to improve the quality and effectiveness of professional military activity involves a deep study of individual psychological characteristics and properties of subjectivity (target, operational, reflective, value, communicative, intellectual, emotional-volitional), as well as the directions of diagnostics of readiness for its implementation in different age periods and in a changing social environment. This, in turn, implies the existence of a system for checking professional suitability for military work from various points of view: competence, educational, legal, psychological, environmental, etc.

References to the special assessment of professional qualities have been preserved to this day since the Ancient World. Around this historical period, the first philosophical prerequisites for the study and evaluation of human abilities to work arise. The scientific substantiation of practical methods of studying individual differences of a person, his

* Corresponding author: prof-ped.gpa@mail.ru 
aptitude for learning and future activities in the future occurs during the formation and development of European sciences at the stage of existence of classical and non-classical scientific rationality.

In our country, systematized ideas about the assessment of a person's professional purpose are carried out according to three main indicators: age, physical and moral. Regular targeted studies of the psychological and physiological capabilities of a person began simultaneously with the advent of aeronautics and the complication of the technical side of military affairs.

Professional selection in Russia has received significant development in the 20s of the XX century, initially based on the socialist approach to the definition of the personality of the «Soviet man». Later, in the 30-80s, the conducted research was characterized mainly by a psychophysiological orientation, using conditioned methods for studying the qualities of the individual and his predisposition to the profession. The most initiatory character during this period was shown by the Laboratory of Economic and Mathematical Research of Novosibirsk State University, the results of which later allowed the transition to a new stage of research based on a personal approach, focused on the assessment of mental and physiological capabilities and functional reserves of the subject of labor activity. The scientists studied the practical experience, scientific research and applied selection methods of Western countries, with the subsequent introduction of some of them into the practice of professional selection in our country. The basic principles of professional selection and the concepts of its socio-psychological cognition were determined.

In the $90 \mathrm{~s}$, due to the socio-economic transformations in the country, the interest in professional selection steadily decreases, since there are objective and subjective reasons for this. In the period of our country's recovery from the economic crisis, the demand for the quality and frequency of professional psychological selection is again increasing, due to the special practical significance for the development of state law enforcement agencies and private commercial enterprises. The reforms carried out in the Armed Forces and other troops form the military psychological service, which is designed to solve, among others, the tasks of professional selection when citizens enroll in military service, including when entering military educational organizations.

In psychology, professional selection is represented as a specialized procedure for determining a person's compliance with a profession, his fitness (unfitness) to master a further specialty and perform specific tasks of professional activity in various conditions of the situation.

O.G. Noskova notes in her works that professional selection is a process of establishing the conformity of an individual to a certain level of a particular specialty (position) [1].

In labor psychology, V.A. Tolochek defines it as a process of practical selection of candidates who are able to ensure the most effective performance of the tasks assigned to them in specific conditions [2].

A.K. Markova notes that professional selection is a complex of measures aimed at identifying individuals suitable for their individual psychological and psycho-physiological qualities, level of education, health and physical development learning and future professional activities corresponding to the profession [3].

B.G. Meshcheryakov and V.P. Zinchenko, professional selection is presented as a procedure for the study and probabilistic assessment of validity for the person to learn a particular specialty.

In sociology, professional selection can be defined as a process that allows an organization or institution to make a certain selection of the most suitable candidates for the established criteria, taking into account the current social and material conditions [4]. It is also defined as the process of selecting the degree and probability of the development of 
medical, psychophysiological and social fitness of individuals to perform work in various conditions using scientific methods [5].

Based on the above opinions, it can be noted that the psychological characteristic and theoretical basis of professional selection is the process of psych diagnostics and forecasting the abilities of the future subject of labor for the upcoming activity. At the same time, it must be considered as a goal, a phenomenon, a process, and a result.

Each activity involves the implementation of the professional competence of its participants, aimed primarily at the effectiveness of solving labor issues and selfimprovement of a person in this activity, which, in turn, determines the essence and characteristics of the functioning of the professional selection system, designed to identify the level of compliance of a person with the requirements of the profession [6].

V.A. Bodrov notes in his works that the relationship between man and labor will allow us to form the necessary knowledge about the psychological patterns of the formation of the subject of labor, the development of his personality as a professional, as well as the role of individual psychological characteristics in this process [7].

In this context, the concept of the system approach of B.F. Lomov deserves great attention, which reflects the basic laws of interrelationships and mutual conditionality of the regulatory and communicative functions of the psyche of the subject of work, psychophysiological and other functions, and structures of the body. This concept defines the hierarchical nature of the interrelationships of these functions in the processes of forming the relationship between the subject and the object of work, the formation and manifestation of their systemic qualities, as well as the role of their structural and functional features in the regulation of labor activity and personal development [8].

\subsection{The objective of the work}

In the literature there are various concepts of professional psychological selection, however, the essence of its activities always remains the same, and the main indicator of its effectiveness (efficiency) is the accuracy of predicting the success of a particular candidate in the upcoming professional activity [9].

Also questions of research features of the organization and implementation of professional psychological selection for various types (functions ) of labor and service activities of N.A. Goncharova [10], E.A. Gubareva [11], I.N. Eliseeva [12], I.A. Erin [13], A.G. Karayani [14], V.I. Koshkarov [15], A.V. Kravchenko [16], V.N. Kalyagin [17], I.V. Obraztsov [18], K.K. Palatova [19], M.S. Panfilova [20], A.S. Oleinikova [21], F.K. Svobodny [22], I.V. Skoblyakova [23], D.V. Smirnov [24], A.A. Dyachkov [25], R.L. Tyupin [26], Ya.P. Shaimov [27], V.K. Shamreya [28], V.E. Shchipakov [29], V.V. Yusupova [30], U.P. Kappinda [31], E. Walter-Vysha [32].

Thus, the problem of effective implementation of professional psychological selection is considered as a problem of mutual correspondence of the individual and the profession. This problem can be solved only if a certain set of requirements is met: both the requirements of the individual for a certain type of professional activity, and the requests of this activity itself for the subjective characteristics of the «person of work».

\section{Results of the research}

Professional selection is necessary for every activity, and it is most important for professions related to activities that are carried out in conditions of high complexity, where significant speed of thought and motor processes, reactions, efficiency in decision-making, and there is a threat to life and health. One of these types of professional service activities is 
military service, the essence of which is the performance of duties in preparation for armed defense and armed defense of the Russian Federation. These duties are associated with the need to unquestioningly perform the tasks set in any conditions, including at the risk of life. Due to the special nature of the duties assigned to military personnel, the life and health of other people, the safety and security of society and the state directly depend on their activities.

The existing system of the Armed Forces and other Troops of the Russian Federation needs specialists in various areas of professional service activities and military accounting specialties, as well as the level of education (qualification), which are necessary both to fulfill the tasks set by the state and society to the military personnel in the legislative and moral aspects.

Professional selection of military personnel is presented to us in the form of a system of certain subjects, forms, methods, means and stages that allow us to predict and assess the mutual compliance of a person and professional activities that will be carried out in specific, normatively defined and sometimes dangerous conditions that require high performance, professional and social responsibility, health, emotional stability, as well as discipline and operational readiness.

Professional selection of permanent military personnel in the Russian Federation structurally includes the following types of selection: social selection; medical selection (determination of the category of fitness for health reasons to perform military service duties); professional psychological selection (determination of the category of professional psychological fitness, including for a specific specialty); educational qualification selection (assessment of the level of general education readiness); assessment of the level of functional development and general physical fitness. Also, professional selection involves conducting various types of verification activities in relation to the candidate, carried out by the competent law enforcement agencies. These types of professional selection represent a certain integrity or system and, in their entirety, allow performing its main social functionto assess the readiness and professional-special compliance of a person with the chosen military profession and a specific specialty.

The most important element of this system is professional psychological selection, which is presented in the form of a set of measures designed to determine the compliance of individual psychological and psychophysiological qualities of candidates with the requirements of military service.

Structurally, the system of professional psychological selection includes its subjects, goals, objectives, conditions, means, stages, methods and methods of implementing measures, criteria and interpretation of the results obtained, as well as an assessment of the effectiveness of the existing selection system with a view to its subsequent improvement.

The subjects of professional psychological selection are a candidate for training (service), a specialist who carries out professional psychological selection activities, and an organization that carries out a certain professional activity, in which the candidate wishes to become a participant.

Each of the subjects of professional psychological selection has subjective qualities, which are presented in the form of various components of subjectivity, allowing them to perform the functions of self-development, self-organization and management of their purposeful activities, which determines their ability to successfully solve the problem of subsequent self-improvement.

Taking into account the existence of this contradiction, we can say that the candidate, as a subject of professional psychological selection, is an emerging personality that has certain natural inclinations and needs, strives for creative self-expression and satisfaction of their interests, aspirations and needs, as well as capable of actively mastering various external influences or resisting them. 
As a subject, in this context, it performs the following tasks: it helps to determine the main directions of professional development of the individual; it allows you to analyze the work of this process and adjust it depending on the result.

Performs the following functions: informative and informative, communicative, adaptive, effective, and others.

S.L. Rubenstein noted that the subject is characterized by conditioned and determined activity, the ability to integrate, self-development, self-regulation, self-movement and selfimprovement.

This statement becomes most relevant when considering the next subject of professional psychological selection - the specialist who carries out its activities, since the further conditionality of not only the existing system of professional psychological selection, but also the further functioning of the personnel component of the organization depends on the results of his professional activity.

\section{Conclusions}

A military specialist who performs professional psychological selection should not only have a documented appropriate level of education and qualifications, but also have an ideological conviction in the need for high-quality (effective and efficient) implementation of all activities, as well as have the necessary and sufficient intellectual, communicative, creative, value and organizational potential, an understanding of the specifics of military service and have practical experience in the relevant professional military activities, for compliance with which the candidate is checked.

Thus, in the system of professional psychological selection, this subject solves the following tasks: organizes, controls, analyzes and practically implements the process of professional psychological selection itself; corrects the functioning of this process depending on its results, ensures its constancy, cyclicality and completeness of implementation. Performs the following functions: organizational and managerial, procedural and evaluative, effective and final, communicative and value-based, and others.

The conditions of professional psychological selection are a set of specially created social and material environment that allows achieving the necessary goals of its organization and through the influence of which the quality of the activities is determined.

This set is characterized by the coordinated activity of all subjects of the professional psychological selection system and includes the event planning system, the equipment of premises and the organization of workplaces for each candidate, the standard established time indicators, the procedure for providing information about the results obtained, and more. The main element of this environment is the creation of a unified environment for all candidates, which subsequently allows for an objective differentiation of the obtained research results.

The means of professional psychological selection are characterized by the presence of psychodiagnostic tools corresponding to its goals, which allows us to determine with a high degree of probability the level of formation and dynamics of the development of individual psychological subject qualities.

Thus, the professional selection of military personnel in Russia includes: social selection; medical selection; professional psychological selection; educational and qualification selection; assessment of the level of functional development and general physical fitness. The internal structure of professional psychological selection includes its subjects, goals, objectives, conditions, means, stages, methods and methods of implementing measures, criteria and interpretation of the results obtained, as well as an assessment of the effectiveness of the existing selection system with a view to its subsequent improvement. The conditions of professional psychological selection are a set 
of specially created social and material environment, as well as psychodiagnostic assessment tools. The main methods of professional psychological selection are the analysis of independent characteristics, testing and questioning, individual conversation and other types of assessment of the level of formation and development of subjective qualities.

\section{References}

1. O.G. Noskova, Psikhologiya truda, 384 (2004)

2. V.A. Tolochek, Modern psychology of labor, 479 (2006)

3. A.K. Markova, Psychology of professionalism, 308 (1996)

4. A.I. Kravchenko, Choice of profession as a sociological phenomenon: questions of theory, Bulletin of the Moscow University. Series 18. Sociology and Political Science, 1, 49-66 (2017)

5. L.D. Filioglo, Sociology of professions of groups, 72 (2014)

6. E.A. Klimov, Psychology of a professional, 76 (1996)

7. V.A. Bodrov, Psychology of professional fitness: A textbook for universities, 511 (2001)

8. B.F. Lomov, Methodological and theoretical problems of psychology, 79 (1984)

9. A.G. Maklakov, Professional psychological selection of personnel. Theory and practice, 824 (2016)

10. Goncharova N. A., Kalashnik A. A. Limiting properties of the personality as an object of psychological analysis in professional psychological selection / / Bulletin of the St. Petersburg University of the Ministry of Internal Affairs of Russia. 1 (73). 206-209. (2017)

11. E.A. Gubareva, O.I. Mironova, Socio-psychological features of the selection of candidates entering military service, 17, 4(149), 5-16 (2018)

12. I.N. Eliseeva, Prerequisites and stages of development of the scientific school of theory and methodology of professional psychological selection in the armed forces, In the book: Psychology of the XXI century: challenges, searches, vectors of development. Collection of materials of the All-Russian Symposium of Psychologists. Under the general editorship of D.V. Sochivko, 134-145 (2019)

13. I.A. Erin, To the question of psychological professional selection and professional aptitude, In the book: Psychology of the XXI century: challenges, searches, vectors of development. Collection of materials of the All-Russian Symposium of Psychologists. Under the general editorship of D.V. Sochivko, 696-702 (2019)

14. A.G. Karayani, On professional psychological selection of citizens in the performance of their military duties, Bulletin of Military Law, 3, 72-73 (2017)

15. V.I. Koshkarov, Yu.N. Salygin, M.N. Sorokin, Professional psychological selection of citizens for military service (2018)

16. A.V. Kravchenko, System-situational analysis of activity in the model approach to professional and psychological selection of candidates, In the collection: Actual problems of practical psychology. Materials of the International Scientific and Practical Conference, 160-163 (2020)

17. R. Makarov, V.N. Kalyagin, Officer-organizer of psychological selection, In the collection: Psychological and pedagogical aspects of improving the training of university students. Materials of the interuniversity student scientific and practical conference with international participation. In 2 parts, 108-110 (2019) 
18. I.V. Obraztsov, The formation of professional psychological selection in the Red Army in the 1920 s., 5, 127-138 (2020)

19. K.K. Palatova, The main directions of psychological research in the field of professional selection in US aviation, In the collection: The human factor in complex technical systems and environments (Ergo-2018). Proceedings of the Third International Scientific and Practical Conference, 361-367 (2018)

20. M.S. Panfilova, M.S. Voloskova, Professional psychological selection as a method of personnel development, In the collection: Problems of modern economics and management. Collection of materials of the IV International Scientific and Practical Conference, 138-142 (2018)

21. A.S. Oleynikova, Psychological aspects of the selection of police personnel: history and modernity, In the collection: Russian Police: three centuries of Service to the Fatherland. Collection of articles of the Anniversary International Scientific Conference. In 2 parts. Edited by V.L. Kubyshko, 235-243 (2019)

22. F.K. Svobodny, B.F. Svobodny, On the issue of the production of psychophysiological research in the process of professional psychological selection of personnel in power structures, International Journal of Psychology and Pedagogy in service activities, $\mathbf{3}$, 77-80 (2020)

23. I.V. Skoblyakova, Accounting for psychological characteristics of personnel in the process of its evaluation and selection, In the collection: Modern technologies of personnel management. Proceedings of the V International Scientific and Practical Conference. Under the scientific editorship of O.S. Reznikova, 139-143 (2018)

24. D.V. Smirnov, Bases and structure of the psychological and pedagogical program for the development of professional psychological fitness of future officers, Scientific opinion, 3, 114-118 (2018)

25. D.V. Smirnov, Empirical study of the effectiveness of the complex of conditions, means and programs for the development of professional psychological fitness of future officers in the educational process of a military university, Letters to the Issue, 8, 254-256 (2017)

26. R.L. Tyupin, E.I. Baraeva, Istoriya organizatsii psikhologicheskogo seleka na letnye spetsializatsii, History of the organization of psychological selection for flight specialties, 19-3, 387-393 (2019)

27. Ya.P. Shaimova, Motivation of candidates for service in the Department of Internal Affairs in the process of professional and psychological selection, 2, 112-114 (2019)

28. V.K. Shamrey, V.V. Yusupov, B.V. Ovchinnikov, The contribution of scientists of the military Medical Academy to ensuring the professional psychological selection of military personnel, 4, 82-87 (2019)

29. V.E. Shchipakov, Normative-legal regulation of psychological support of militaryprofessional activity (professional psychological selection), Vestnik voennogo prava, 4, 76-81 (2019)

30. V.V. Yusupov, V.K. Shamrey, V.A. Korzunin, B.V. Ovchinnikov, Military Medical Academy in the formation and development of professional psychological selection of military personnel, Izvestiya Rossiyskoy Voenno-meditsinskoy akademii, 3, 5-12 (2019)

31. U.P. Kanning, Die Psychologie der Personenbeurteilung, 81 (2017)

32. E. Walter-Busch, Arbeits- und Organisations psychologie im Überblick, 155 (2018) 